\title{
Effect of Partial Replacements of Coarse Aggregate by Polycarbonate Plastic Waste on the First Crack Impact Resistance of Concrete Beam
}

\author{
Mustafa M. Al-Tayeb ${ }^{1 *} \quad$ Ismail Al Daoor $^{1} \quad$ Nagham K. Ali-Hasan $^{1} \quad$ Abdullah M. Zeyad ${ }^{2}$ \\ 1.School College of Applied Engineering and Urban Planning, University of Palestine, PO Box 1075, Gaza, \\ Palestine \\ 2.Civil Engineering, College of Engineering, Jazan University, 45142 Jazan, Saudi Arabia
}

\begin{abstract}
This paper examines impact strength properties of concrete in which different amounts $2.5 \%, 5 \%$ and $10 \%$ of polycarbonate plastic waste particles were used as coarse aggregate replacement. For each amount, six beams of $100 \mathrm{~mm} \times 100 \mathrm{~mm} \times 500 \mathrm{~mm}$ were subjected to $4.5 \mathrm{~kg}$ hammer from $457 \mathrm{~mm}$ height. The number of blows of the hammer required to induce the first visible crack of the beams were recorded. The results are presented in terms of impact energy required for the first visible crack. The concrete mixtures exhibited ability to absorb a large amount of impact energy. The polycarbonate plastic waste increased the first crack impact energy of concrete. Keywords: Polycarbonate plastic waste; Cement concrete; Compressive strength; First crack impact energy. DOI: $10.7176 / \mathrm{JEES} / 10-2-06$
\end{abstract}

Publication date: February $29^{\text {th }} 2020$

\section{Introduction}

Polycarbonate plastic as one of the most popular wastes can be present in any disposal site regardless of the source of collection, whether it is commercial, residential or a tourist site. It constitutes about $15-20 \%$ of the material recovery facilities outputs [1]. Unfortunately, plastic products are formed from several toxic chemicals which pollute soil, air and water. Disposal of plastic waste (PW) in nature is taken into account as a huge problem. It has very low biodegradability and takes up to 450 year to decompose in landfills [2]. Hence, there is an urgent need to identify alternative solutions to reuse the plastic waste for other applications, and concrete has been identified to be one of the feasible options. On the other hand, the concrete has limited properties such as low tensile strength, low ductility, and low energy absorption [3]. A wide range of literatures has already been done on the application of PW in concrete mixture [4-27], such as poly vinyl chloride (PVC) pipe [4], polyethylene terephthalate (PET) bottle [5-9], thermo- setting plastics [10], high density polyethylene (HDPE) [11], shredded and recycled plastic waste [12-14], expanded polystyrene foam (EPS) [15,16], polycarbonate [17], glass reinforced plastic (GRP) [18], polyurethane foam [19,20], poly-propylene fiber [21] as an aggregate, fiber and powder [11,22]. In effect, not all waste materials are suitable to use in concrete nor it can beneficially integrate its properties as part of the cementitious binder or as aggregates [23]. Therefore, it is important to investigate the effect of waste materials on the properties of produced concretes. Generally, PW as the component of municipal solid waste is becoming a major research issue for possible use in concrete, particularly in self-compacting concrete (SCC). Choi et al. [11,12] examined the properties of mortar and concrete containing PW as fine aggregate. In the same regard, As'ad et al. [24] prepared SCCs via utilizing PW as fiber form and investigated the fresh state behavior of the produced concrete. Soroushian et al. [25] stated that polypropylene is used only as synthetic fibers in order to increase the toughness of concrete. Hinıslioglu and Agar [26] investigated the possibility of using high density polyethylene as additives to asphalt concrete. Likewise, the effect of PW bottles on concrete behavior at different w/c ratios had been investigated by Albano et al. [9]. Pezzi et al. [27] utilized plastic particles as aggregate in concrete and evaluated the chemical, physical and mechanical properties. Despite aforementioned studies, there is a shortage in literatures that used PW as powder form and cement-substitution materials. Al-Tayeb et al. [28] investigated the effect of partial replacements of sand by waste rubber on the fracture characteristics of concrete. They found that addition of waste tire in concrete enhanced the fracture properties, while both compressive and flexural strengths were decreased. Al-Tayeb et al. [29-31] conducted tests to examine the performance of rubberized concrete with $5 \%, 10 \%$ and $20 \%$ replacements by volume of sand by waste crumb rubber under static and impact load conditions. Their results showed that the addition of rubber improved the impact load behavior of concrete.

However, the mechanical properties of concrete with partial replacements of coarse aggregate by polycarbonate plastic waste under impact load are yet to be explored. In this study, effects of partial replacements of coarse aggregate by polycarbonate plastic waste on the performance of concrete under low velocity impact loading were investigated. Specimens were prepared for $2.5 \%, 5 \%$ and $10 \%$ replacements by volume coarse aggregate. For each case, six beams of $100 \mathrm{~mm} \times 100 \mathrm{~mm} \times 500 \mathrm{~mm}$ were subjected to $4.5 \mathrm{~kg}$ hammer from $457 \mathrm{~mm}$ height. The number of blows of the hammer required to induce the first visible crack of the beams were recorded. 


\section{Materials and methods}

\subsection{Materials}

For the development of the present research, conventional concrete compounds were prepared with type I ordinary Portland cement. The cement chemical compositions are presented in Table 1.

Table 1: Chemical compositions of cement

\begin{tabular}{cc}
\hline Item & Percentage in Cement (\%) \\
\hline \multicolumn{3}{c}{ Oxide compositions } \\
\hline $\mathrm{SiO} 3$ & 19.98 \\
\hline $\mathrm{A} 2 \mathrm{O} 3$ & 5.17 \\
\hline $\mathrm{Fe} 2 \mathrm{O} 3$ & 3.27 \\
\hline $\mathrm{CaO}$ & 64.17 \\
\hline $\mathrm{MgO}$ & 0.79 \\
\hline $\mathrm{SO} 3$ & 2.38 \\
\hline Total alkalis & 0.90 \\
\hline Insoluble Residue & 0.20 \\
\hline Loss on Ignition & 2.50 \\
\hline $\mathrm{C} 3 \mathrm{~S}$ & 63.13 \\
\hline $\mathrm{C} 2 \mathrm{~S}$ & 9.61 \\
\hline $\mathrm{C} 3 \mathrm{~A}$ & 8.18 \\
\hline $\mathrm{C} 3 \mathrm{AF}$ & 9.94 \\
\hline
\end{tabular}

The maximum coarse aggregate size was $10 \mathrm{~mm}$, and the fine aggregate was graded natural silica sand. The specific gravities of fine and coarse aggregates were 2.64 and 2.62 respectively. Concrete mixes were prepared with replacements of coarse aggregate volume by $2.5,5$, and $10 \%$ with polycarbonate plastic waste. The particle size distribution of polycarbonate plastic waste is given in Table 2.

Table 2: Particle size distribution of coarse aggregate and polycarbonate plastic waste

\begin{tabular}{lcc}
\hline Sieve size $(\mathrm{mm})$ & \multicolumn{2}{c}{ Cumulative passing $(\%)$} \\
\cline { 2 - 3 } & Coarse Aggregate & $\mathrm{PW}$ \\
\hline 14 & 100 & 100 \\
10 & 94.5 & 24 \\
5 & 66.3 & 4.2 \\
3.15 & 21.2 & 0.9 \\
2.36 & 1.5 & 0 \\
1.18 & 0 & \\
\hline
\end{tabular}

The composition of normal concrete is presented in Table 3.

The compositions of the plastic waste concrete are presented in Table 4. Figure 1 shows the images of polycarbonate plastic waste sample (relative density, 0.8) used in the present study.

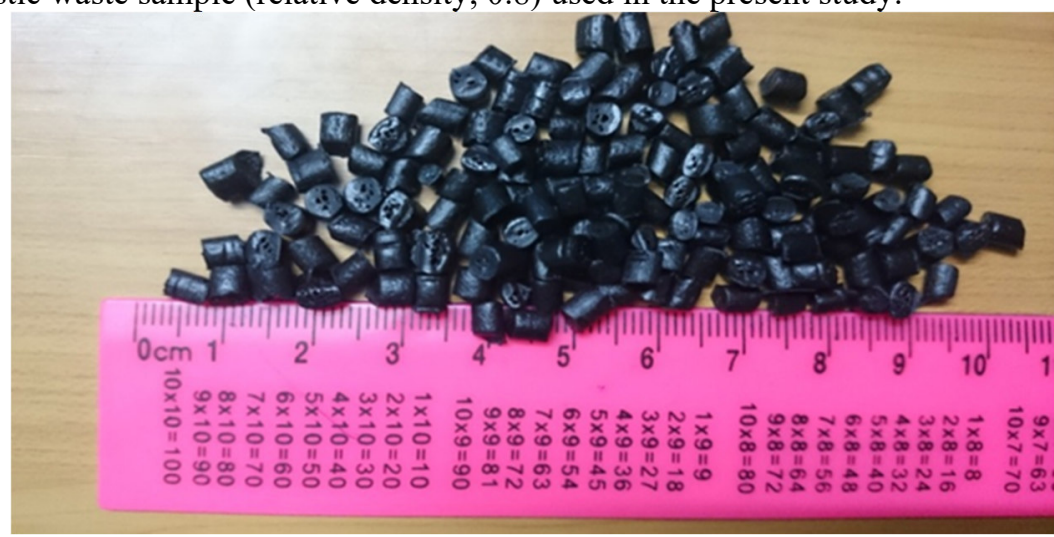

Figure 1: Images of the polycarbonate plastic waste.

Table 3: Mixture properties of normal concrete

\begin{tabular}{ccccc}
\hline Unit & Cement & Water & Fine aggregate & Coarse aggregate \\
\hline Weight $(\mathrm{kg})$ & 454 & 195 & 670 & 1072 \\
Volume $\left(\mathrm{m}^{3}\right)$ & 144 & 195 & 251 & 405 \\
\hline
\end{tabular}




\begin{tabular}{ccccccc}
\multicolumn{7}{c}{ Table 4: Mixture properties of plastic concrete } \\
\hline Unit & $\begin{array}{c}\text { Plastic } \\
\text { percent }\end{array}$ & Cement & Water & $\begin{array}{c}\text { Fine } \\
\text { aggregate }\end{array}$ & $\begin{array}{c}\text { Coarse } \\
\text { aggregate }\end{array}$ & $\begin{array}{c}\text { Plastic } \\
\text { waste }\end{array}$ \\
\hline Weight $(\mathrm{kg})$ & - & 454 & 195 & 670 & 1045 & 8.0 \\
Volume $\left(\mathrm{m}^{3}\right)$ & $2.5 \%$ & 144 & 195 & 251 & 395 & 10.0 \\
Weight $\left(\mathrm{kg}^{3}\right)$ & - & 454 & 195 & 670 & 1018 & 16.2 \\
Volume $\left(\mathrm{m}^{3}\right)$ & $5 \%$ & 144 & 195 & 251 & 384 & 20.3 \\
Weight $\left(\mathrm{kg}^{3}\right)$ & - & 454 & 195 & 670 & 965 & 32.4 \\
Volume $\left(\mathrm{m}^{3}\right)$ & $10 \%$ & 144 & 195 & 251 & 364 & 40.5 \\
\hline
\end{tabular}

For the compression test, three cubic specimens of $100 \mathrm{~mm}$ side were prepared for each type. For split-tensile test, three cylinders of $160 \mathrm{~mm}$ height and $100 \mathrm{~mm}$ diameter were prepared with the aforementioned proportions of polycarbonate plastic waste. In the case of impact test, 6 specimens of $100 \mathrm{~mm} \times 100 \mathrm{~mm} \times 500 \mathrm{~mm}$ beams were prepared for each type. All specimens were cured in water for 28 days in accordance with ASTM C 192/C192M$98[32]$.

\subsection{Experimental set-up and procedure}

Figure 2 shows the hammer of modified proctor which was used as drop weight machine to investigate the impact resistance of plastic concrete.

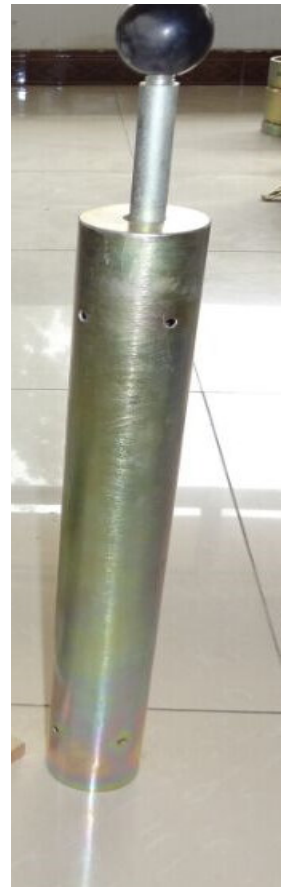

Fig. 2: Hammer of modified proctor.

For impact test, 6 specimens of $100 \mathrm{~mm} \times 100 \mathrm{~mm} \times 500 \mathrm{~mm}$ beams were prepared for each type. A $4.5 \mathrm{~kg}$ hammer $51 \mathrm{~mm}$ in diameter with a circular flat face was raised to $457 \mathrm{~mm}$ above the specimen, and then released by following the procedure Mohammadi et al. [33]. The hammer was dropped repeatedly and the number of blows required to produce the first visible crack in the specimens were recorded. The impact energy (U) imparted by the hammer for ' $n$ ' number of bows with mass of hammer $(\mathrm{m})$ and a hammer velocity ' $v$ ' was calculated as follows:
$\mathrm{U}=n * 1 / 2\left(\mathrm{~m} v^{2}\right)$
(1) where,
$v=\sqrt{2 *(0.9 g) * h}$

$\mathrm{g}=$ gravitational acceleration and $=$ drop height of hammer. The factor, 0.9 accounts for effect of the air resistance and friction between the hammer and the guide rails [34].

\section{Results and discussion}

\subsection{Slump test}

One of the problems when adding polycarbonate plastic waste into the concrete is the reduction of workability of the concrete. The procedure of slump test was according to ASTM C143 [35]. As shown in Figure 3 the slump of the concrete decreases with increase in plastic content. As $10 \%$ of coarse aggregate volume is replaced by polycarbonate plastic waste, the slump reduces to $35 \mathrm{~mm}$ only where it still within the designed slump for this 
concrete $(30-60 \mathrm{~mm})$. The reduction of the slump with increase in the amount of plastic particles in the concrete might be attributed to the increase in the interior voids and the rough surface of the plastic particles which might result in increasing friction between the fresh concrete ingredients. Generally, superplasticizer produced the same electrostatic charges on the cement particles surface. This resulted in the repulsion among the cement particles, prevented the coagulation and minimized the interior voids and the friction between the fresh concrete ingredients.

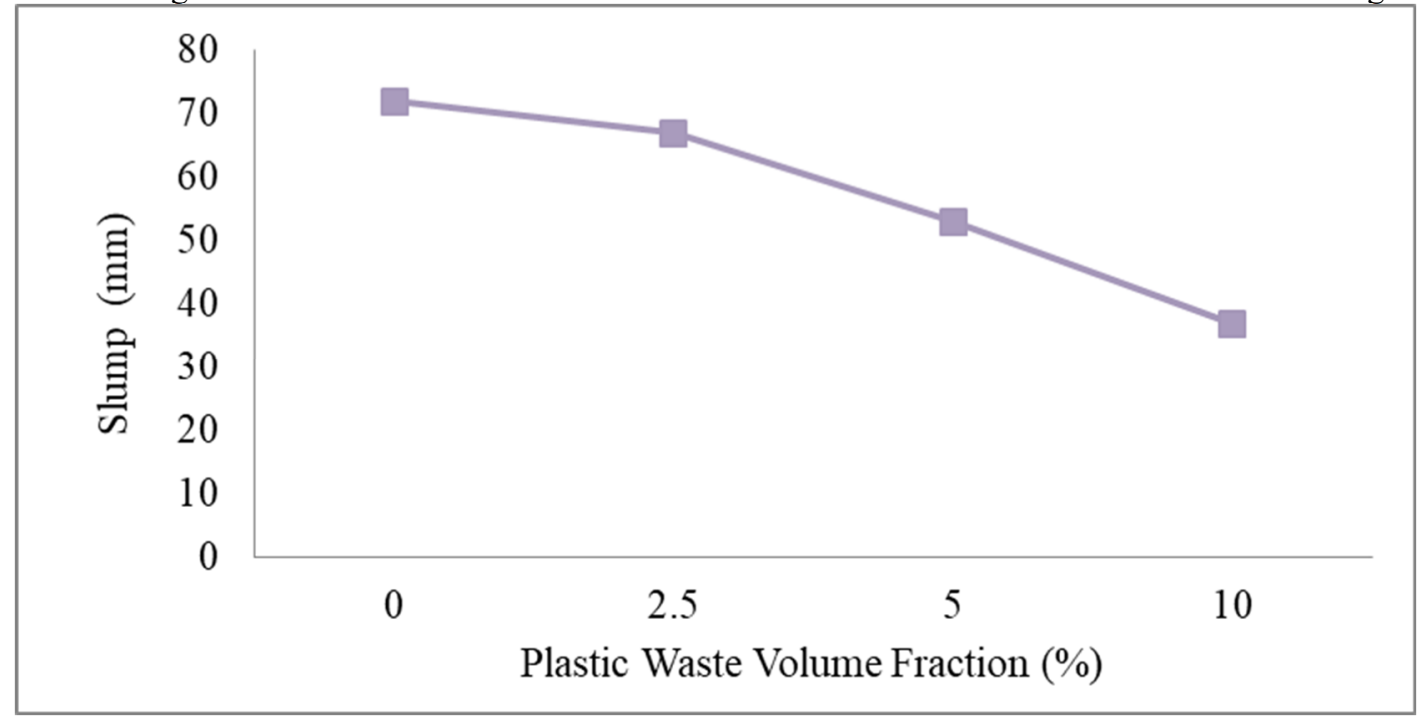

Fig. 3: Effect of coarse aggregate replacement ratio on slump of plastic concrete

\subsection{Compressive stress and modulus of elasticity}

The compressive strength and modulus of elasticity were tested according to ASTM C 39 [36] and ASTM C 469 [37]. The results presented in Table 5 show a systematic reduction in concrete compressive strength with the increase of plastic content. The initial 28-day compressive strength of almost 43.7 MPa decreased to about 25.7 MPa when $10 \%$ replacement of coarse aggregate by polycarbonate plastic waste was made. The compressive stress are reduced by 19,36 and $41 \%$ with the coarse aggregate replacement by polycarbonate plastic by $2.5,5$, and $10 \%$ of volumes, respectively. Similar is the case of elastic modulus which reduces by 5,13 and $23 \%$.

Although strength reduction is certainly a negative property that may hinder the use of plastic waste, elastic modulus results appear the positive effect in the form of the failure mode. The results sustained a much higher deformation than the control mix. With plastic content $10 \%$, the samples exhibited significant elastic deformation, which was retained on unloading. Thus, flexibility and ability to deform elastically is increased significantly.

The reduction of compressive stress of concrete is attributed to the weak compressive stress of the plastic particles compared to the compressive stress of the coarse aggregate. In addition to that the weak bond between plastic particles and the cement paste and the deformability of the plastic particles, which result in the initiation of cracks around the plastic particles in a fashion similar to that, occur in normal concrete due to air voids, cause reduction in stress. This reduction may also be due to grading, as the particle size of coarse aggregate used in this research was different than the particle size of the plastic waste which increased the voids between the aggregate. Table 5: Compressive strength and modulus of elasticity

\begin{tabular}{ccc}
\hline Plastic percent $\%$ & Average compressive stress (Mpa) & Average elastic modulus $\left(\mathrm{kN} / \mathrm{mm}^{2}\right)$ \\
\hline $0 \%$ & 43.7 & 31.1 \\
\hline $2.5 \%$ & 35.5 & 29.4 \\
\hline $5 \%$ & 28.2 & 27.0 \\
\hline $10 \%$ & 25.7 & 23.7 \\
\hline
\end{tabular}

For split-tensile test, three cylinders of $160 \mathrm{~mm}$ height and $100 \mathrm{~mm}$ diameter were used for each concrete mixture. The test was carried out in accordance with the procedures stated in the ASTM C 496 standard [38]. Fig .4 shows the result of splitting-tensile test, which indicates that the plain concrete is yielded at $3.8 \mathrm{MPa}$, while with the coarse aggregate replacement $(2.5,5$, and $10 \%$ of volumes $)$ by polycarbonate plastic waste it is reduced by 23 , 34 and $50 \%$ respectively. This is also consistent with the result of compression stress. 


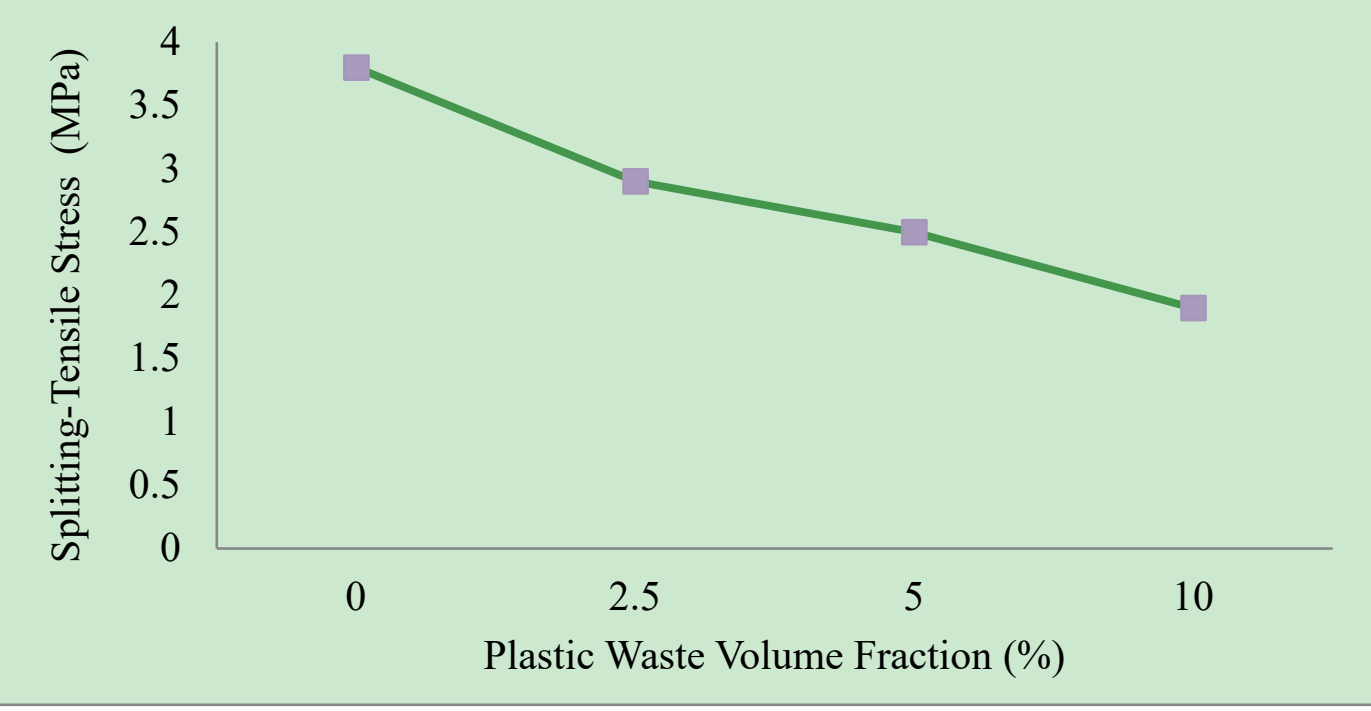

Fig. 4: Splitting tensile stress against volume fraction of plastic waste.

\subsection{Impact test}

Six concrete beams of each type of mixtures were prepared for this test. The tested beams were $100 \mathrm{~mm} \times 100 \mathrm{~mm}$ $\times 500 \mathrm{~mm}$. The numbers of impact blows required for producing the first visible crack, for each type of concrete specimen were recorded in Table 6, and the corresponding plot is shown in Figs. 5.

Figs. 6 present the results in terms of first crack impact energy. The results show that the first crack resistance increases by 33,64 and $41 \%$ with $2.5,5$, and $10 \%$ of plastic replacements respectively. The enhanced first crack impact resistance is due to the enhanced flexibility of the composite mix by the addition of plastic. The increases in flexibility are attributed to the high ductility of plastic which when added to the concrete, improves the mix ductility [30] and the ability to absorb the impact load.

Table 5: Impact test results for plain and polycarbonate plastic concrete.

\begin{tabular}{|c|c|c|c|c|c|}
\hline $\begin{array}{c}\text { Type } \\
\text { of } \\
\text { concrete }\end{array}$ & $\begin{array}{c}\text { Plastic } \\
(\%)\end{array}$ & $\begin{array}{l}\text { No. of blows of } \\
\text { first crack }\end{array}$ & $\begin{array}{l}\text { Average no. of } \\
\text { blows }\end{array}$ & $\begin{array}{c}\text { Impact energy } \\
(\mathrm{kN} \mathrm{mm}) \\
\text { of first crack }\end{array}$ & $\begin{array}{l}\text { Average impact } \\
\text { energy }(\mathrm{kN} \mathrm{mm})\end{array}$ \\
\hline \multirow[t]{6}{*}{ Plain } & 0 & 6 & \multirow[t]{6}{*}{6.5} & 108.9 & \multirow[t]{6}{*}{118.0} \\
\hline & 0 & 5 & & 90.7 & \\
\hline & 0 & 7 & & 127.0 & \\
\hline & 0 & 8 & & 145.2 & \\
\hline & 0 & 7 & & 127.0 & \\
\hline & 0 & 6 & & 108.9 & \\
\hline \multirow{18}{*}{$\begin{array}{l}\text { Coarse } \\
\text { aggregate } \\
\text { replaced } \\
\text { with } \\
\text { plastic } \\
\text { waste }\end{array}$} & $5 \%$ & 10 & \multirow[t]{6}{*}{8.7} & 181.5 & \multirow[t]{6}{*}{157.3} \\
\hline & $5 \%$ & 8 & & 145.2 & \\
\hline & $5 \%$ & 6 & & 108.9 & \\
\hline & $5 \%$ & 11 & & 199.6 & \\
\hline & $5 \%$ & 9 & & 163.3 & \\
\hline & $5 \%$ & 8 & & 145.2 & \\
\hline & $10 \%$ & 12 & \multirow[t]{6}{*}{10.7} & 217.8 & \multirow[t]{6}{*}{193.6} \\
\hline & $10 \%$ & 9 & & 163.3 & \\
\hline & $10 \%$ & 6 & & 108.9 & \\
\hline & $10 \%$ & 10 & & 181.5 & \\
\hline & $10 \%$ & 13 & & 235.9 & \\
\hline & $10 \%$ & 14 & & 254.1 & \\
\hline & $15 \%$ & 8 & \multirow[t]{6}{*}{9.2} & 145.2 & \multirow[t]{6}{*}{166.4} \\
\hline & $15 \%$ & 10 & & 181.5 & \\
\hline & $15 \%$ & 13 & & 235.9 & \\
\hline & $15 \%$ & 8 & & 145.2 & \\
\hline & $15 \%$ & 7 & & 127.0 & \\
\hline & $15 \%$ & 9 & & 163.3 & \\
\hline
\end{tabular}




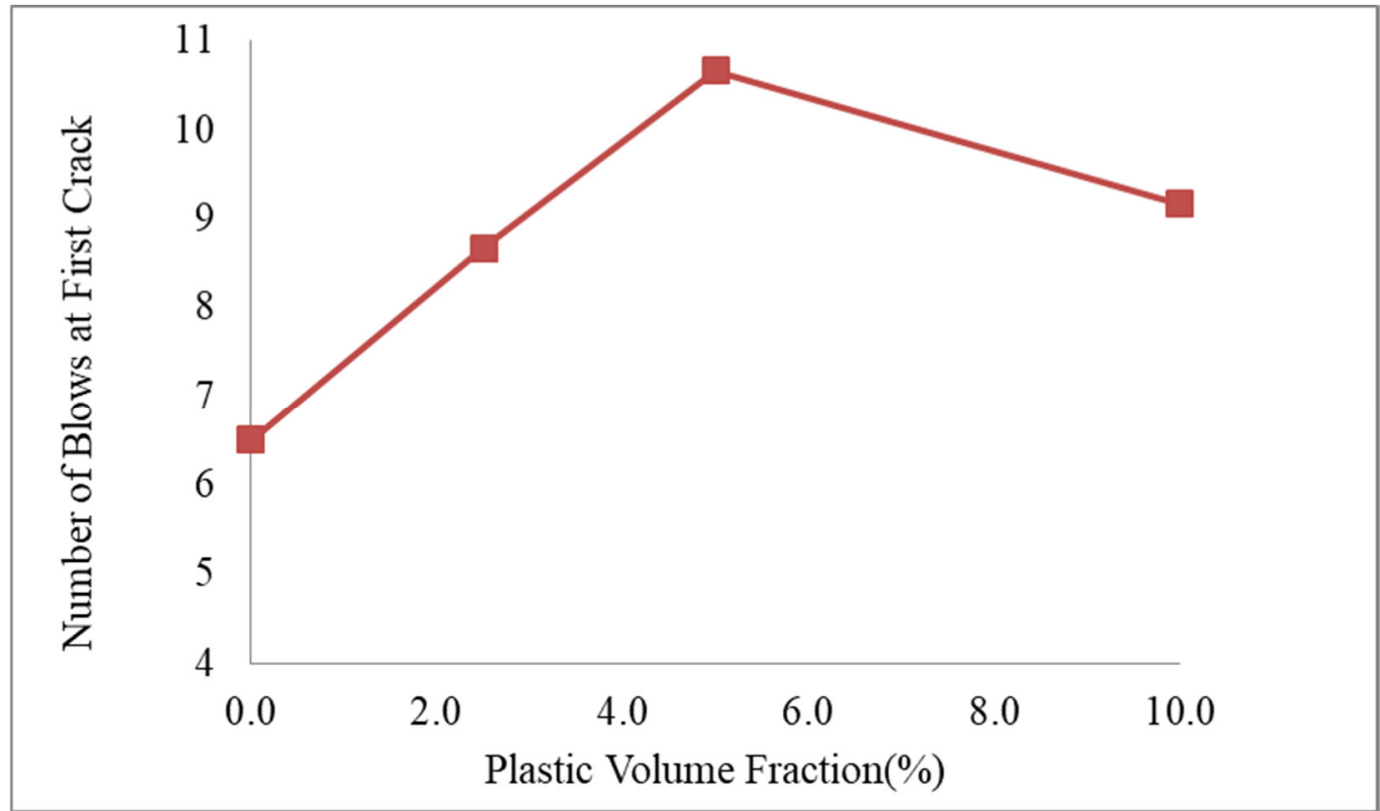

Fig. 5: First crack impact resistance against volume fraction of plastic.

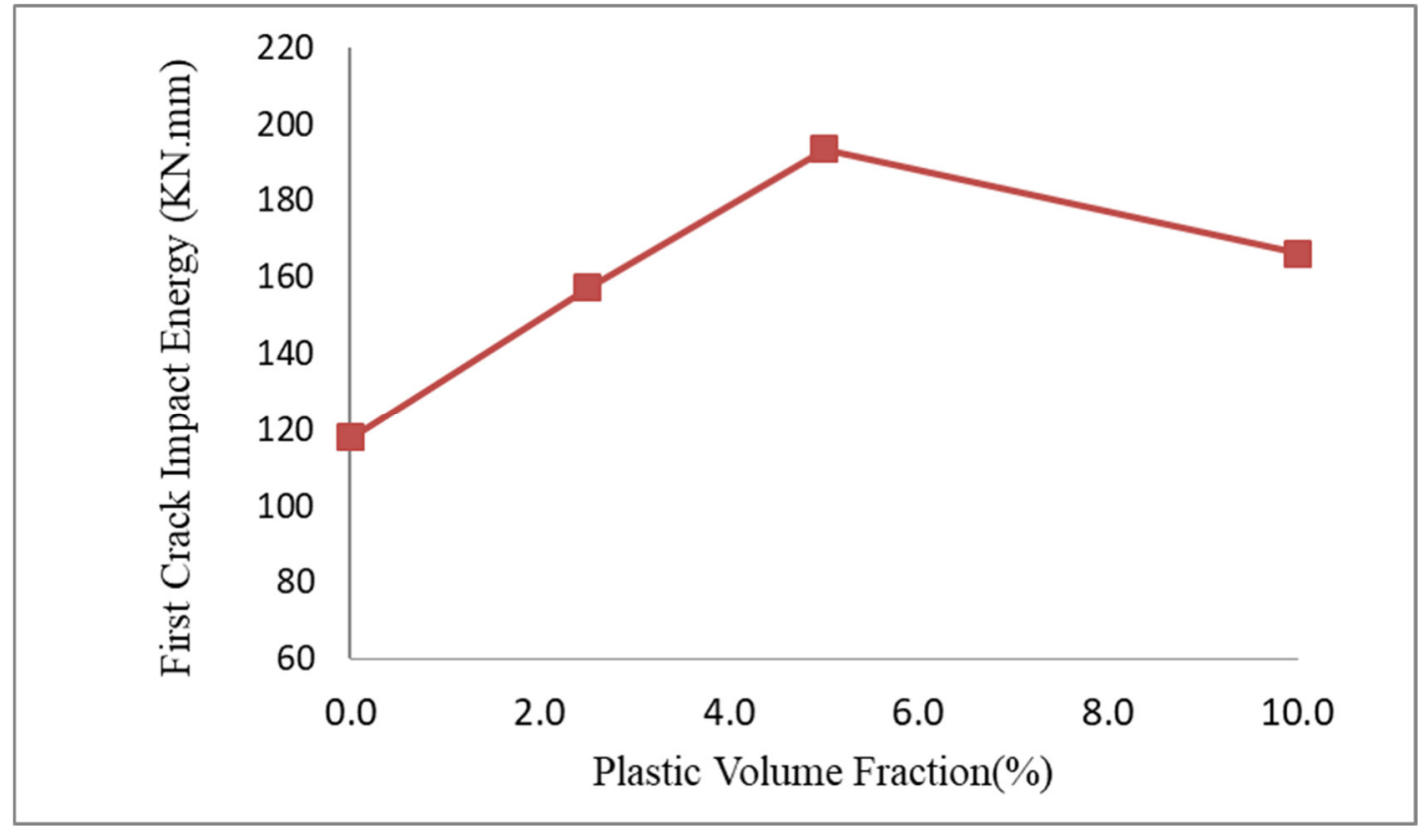

Fig. 6: First crack impact energy against volume fraction of plastic.

\section{Conclusion}

This study examined how different volume fractions of polycarbonate plastic waste affect the mechanical properties of concrete under static and impact load. The following conclusions were found:

- The slump of the plastic concrete decreases with increase in polycarbonate plastic content. Superplasticizer with $1 \%$ will solve this problem.

- The results show that the compressive stress and modulus of elasticity decrease with increase in polycarbonate plastic content.

- The results show that the splitting-tensile stress decreases with increase in polycarbonate plastic content.

- The first crack resistance increases by 33, 64 and $41 \%$ with $2.5,5$, and $10 \%$ of polycarbonate plastic replacements respectively. The enhanced first crack impact resistance is due to the enhanced flexibility of the composite mix by the addition of plastic. 


\section{Reference}

[1] Turkish Court of Accounts, Waste Management in Turkey National Regulations and Evaluation of Implementation Results, Performance Audit Report, 2007, p. 81.

[2] U.S. National Park Service; Mote Marine Lab, Sarasota, FL and "Garbage In, Garbage Out", Audubon magazine, 1998

[3] Wang, Y., Wu , H.C. and Li, V.C., Concrete Reinforcement with Recycled Fibers. J. Mater. Civ.Eng. 2000 , $12(4), 314-319$

[4] S. Akçaözog lu, C.D. Atis, K. Akçaözog lu, An investigation on the use of shredded waste PET bottles as aggregate in lightweight concrete, Waste Manage. (Oxford) 30 (2) (2010) 285-290.

[5] MoEU, Information received during the Eionet consultation of the paper, Email of 14 November 2012 from Arzu Nuray, Turkish Ministry of Environment and Urbanisation, 2012.

[6] Hilles, Mahmoud Mazen, and Mohammed M. Ziara. "Mechanical behavior of high strength concrete reinforced with glass fiber." Engineering Science and Technology, an International Journal (2019).

[7] State Institute of Statistics (SIS), Solid Waste Statistics, 2004.

[8] U.S. National Park Service; Mote Marine Lab, Sarasota, FL and "Garbage In, Garbage Out", Audubon magazine, 1998.

[9] A. Hassani, H. Ganjidoust, A.A. Maghanaki, Use of plastic waste (poly-ethylene terephthalate) in asphalt concrete mixture as aggregate replacement, Waste Manage. Res. 23 (4) (2005) 322-327.

[10] Y.W. Choi, D.J. Moon, Y.J. Kim, M. Lachemi, Characteristics of mortar and concrete containing fine aggregate manufactured from recycled waste polyethylene terephthalate bottles, Constr. Build. Mater. 23 (8) (2009) 2829-2835.

[11] C. Albano, N. Camacho, M. Hernandez, A. Matheus, A. Gutierrez, Influence of content and particle size of waste pet bottles on concrete behavior at different w/c ratios, Waste Manage. (Oxford) 29 (10) (2009) 27072716.

[12] Y.W. Choi, D.J. Moon, J.S. Chung, S.K. Cho, Effects of waste PET bottles aggregate on the properties of concrete, Cem. Concr. Res. 35 (4) (2005) 776-781.

[13] S.B. Kim, N.H. Yi, H.Y. Kim, J.H.J. Kim, Y.C. Song, Material and structural performance evaluation of recycled PET fiber reinforced concrete, Cem. Concr. Res. 32 (3) (2010) 232-240.

[14] S.C. Kou, G. Lee, C.S. Poon, W.L. Lai, Properties of lightweight aggregate concrete prepared with PVC granules derived from scraped PVC pipes, Waste Manage. (Oxford) 29 (2) (2009) 621-628.

[15] T.R. Naik, S.S. Singh, C.O. Huber, B.S. Brodersen, Use of post-consumer waste plastics in cement-based composites, Cem. Concr. Res. 26 (10) (1996) 1489-1492.

[16]P. Panyakapo, M. Panyakapo, Reuse of thermosetting plastic waste for lightweight concrete, Waste Manage. 28 (2008) 1581-1588.

[17] A. Al-Manaseer, T. Dalal, Concrete containing plastic aggregates, Concr. Int. 19 (1997) 47-52.

[18] Mermerdaş, Kasım, et al. "Effect of aggregate properties on the mechanical and absorption characteristics of geopolymer mortar." Engineering Science and Technology, an International Journal 20.6 (2017): 1642-1652.

[19] P. Soroushian, J.S. Plasencia, S. Ravanbakhsh, Assessment of reinforcing effects of recycled plastic and paper in concrete, ACI Mater. J. 100 (2003) 203-207.

[20] A. Kan, R. Demirboga, A novel material for lightweight concrete production, Cem. Concr. Compos. 31 (2009) $489-495$.

[21]A. Kan, R. Demirboga, A new technique of processing for waste-expanded polystyrene foams as aggregates, J. Mater. Process. Techno. 209 (2009) 2994-3000.

[22] P. Asokan, M. Osmani, A.D.F. Price, Improvement of the mechanical properties of glass fibre reinforced plastic waste powder filled concrete, Constr. Build. Mater. 24 (2010) 448-460.

[23] Azo. Build, Avoidance of waste: beneficial use of industrial by-products as constituents of concrete (The third information sheet prepared by the environmental working party of the concrete society's material group), Concrete 37 (5) (2003) 43-45.

[24] S. As'ad, P. Gunawan, M. Alaydrus, Fresh state behavior of self compacting concrete containing waste material fibres, The Twelfth East Asia-Pacific Conference on Structural Engineering and Construction, Proc. Eng. 14 (2011) 797-804.

[25]P. Soroushian, F. Mirza, A. Alhozaimy, Permeability characteristics of polypropylene fiber reinforced concrete, ACI Mater. J. 92 (3) (1995) 291-295.

[26] S. Hinıslioglu, E. Agar, Use of waste density polyethylene as bitumen modifier in asphalt concrete mix, Mater. Lett. 58 (2004) 267-271.

[27]L. Pezzi, P. De Luca, D. Vuono, F. Chiappetta, A. Nastro, Concrete products with waste's plastic material (bottle, glass, plate), Mater. Sci. Forum 514 (2) (2006) 1753-1757. 
[28] Al-Tayeb , M.M. ; Abu Bakar , B. H. ; Akil , H.M. ; Ismail , H. Effect of partial replacements of sand and cement by waste rubber on the fracture characteristics of concrete. Polym.-Plast. Technol. Eng. 2012 , 51 (6), 583-589.

[29] Al-Tayeb M.M, Abu Bakar B.H, Ismail. H, and Akil. H.M, Effect of partial replacement of sand by recycled fine crumb rubber on the performance of hybrid rubberized-normal concrete under impact load: experiment and simulation. Journal of Cleaner Production. 2013, 59 (15), 284-289

[30] Al-Tayeb, M. M., Ismail, H., Dawoud, O., Wafi, S. R., \& Al Daoor, I. (2017). Ultimate failure resistance of concrete with partial replacements of sand by waste plastic of vehicles under impact load. International Journal of Sustainable Built Environment, 6(2), 610-616.

[31] Al-Tayeb, M. M., Abu Bakar, B. H., Ismail, H., \& Akil, H. M. (2013). Impact Energy for the First Crack of Reinforced Concrete with Partial Replacements of Sand by Fine Crumb Rubber. In Advanced Materials Research Vol. 701,pp. 286-290

[32] American Society for Testing and Materials (ASTM) C192/192. Standard practice for making and curing concrete test specimens in the laboratory, vol. 4.02, West Conshohocken, PA, USA; (2006).

[33] Mohammadi , Y. ; Carkon-Azad , R. ; Singh , S.P. ; Kaushik , S.K. Impact resistance of steel fibrous concrete containing fibres of mixed aspect ratio. Constr. Build. Mater. 2009 , 23 (1), 183-189.

[34] Xu , H. Specialized fiber reinforced concretes under static and impact loading, PhD thesis, University of British Columbia, Heritage Branch, Canada (1987).

[35] American Society for Testing and Materials (ASTM) C143. Standard Test Method for Slump of Hydraulic Cement Concrete', vol. 04.02, 1995., West Conshohocken, PA, USA.

[36] American Society for Testing and Materials (ASTM) C39/C39 M-01, Test Method for Compressive Strength of Cylindrical Concrete Specimens, Annual Book of ASTM Standards, Pennsylvania (2001).

[37] American Society for Testing and Materials (ASTM) C469-94, Standard Test Method for Static Modulus of Elasticity and Poisson's Ratio of Concrete in Compression, Annual Book of ASTM Standards, Pennsylvania (1994).

[38]ASTM, C. 496, Standard test method for splitting tensile strength of cylindrical concrete specimens. United States: ASTM International, 2004. 